\title{
"WILL YOU TO MY DISCOURSE VOUCHSAFE AN EARE?":" WOMEN DRAMATISTS' NEGOTIATION OF GENDER AND GENRE ON THE PUBLIC STAGE AROUND 1700
}

\author{
MARGUÉRITE CORPORAAL \\ University of Leiden
}

\begin{abstract}
Despite the growing influence of women in the theatrical world during the late seventeenth-and early eighteenth-century, women dramatists working for the public stage were accused of lascivious behaviour, as a result of the public setting of the playhouse in which their self-expression could be heard. In their tragedies The Royal Mischief (1696), The Fatal Friendship (1698) and Antiochus the Great; or, The Final Relapse (1701) the female dramatists Mary Delarivier Manley, Catherine Trotter and Jane Wiseman negotiated female utterance in several ways. Moreover, these women dramatists legitimisation of woman's public voice and their own public theatrical voices was accompanied by their revision of tragic generic conventions concerning error, closure, transgression and transcendence. In these respects these women playwrights contributed to processes of cultural transformation with regard to gender and genre.
\end{abstract}

The admittance of female actresses to the English public stage in 1660 was followed by a period in which women started to become involved with writing for the public theatre: ${ }^{2}$ Frances Boothby wrote a tragicomedy, Marcelia; or the

1. The quotation is taken from Elizabeth Polwhele's tragedy The Faithful Virgins (act I), a play which was performed on the London public stage by 1670 , "apoynted to be acted by the dukes Company of Actors" (f.49). MS. Rawls Poet. 195. Ff. 49-78. The Bodleian Library.

2. There is some dispute about the exact date when the first English actress performed on the public stage; however, on the basis of evidence from Pepys' diary, historians agree that this date could be December 8, 1660, when an as yet unidentified woman played the role of Desdemona in a production of Othello, the Moor of Venice. See Beate Braun 1995: 110-114. 
Treacherous Friend for the public stage by 1669, and Elizabeth Polwhele and Aphra Behn had plays performed by the early 1670s. ${ }^{3}$ However, since Boothby only wrote one tragicomedy, and since Polwhele already ceased her activities as female playwright by 1671, for a long time Aphra Behn was the only woman writing plays for public performance. ${ }^{4}$

Some tragedies were written by women between 1678 and the 1690s, but these were specifically presented as drama that was not meant to be staged. Anne Lee Wharton wrote Love's Martyr, or Witt above Crowns (1688), which was intended as closet drama, that is, a play designed for private reading. The tragedy is addressed to Mrs Mary Howe, being embedded in the traditions of female address, for Wharton (1685: A1v) concludes that her address to Mrs Howe "cannot aspire to the name of dedication". Wharton also claims that the play was "never deserved nor was ever designed to be publick" Likewise, Anne Finch wrote The Triumph of Love and Innocence (1688) as a play which was not meant for public staging.

According to some historians, the fact that by the 1680s women writers resorted again to closet drama can be explained by the disappearance of direct patronage and support of the public theatre by the monarchy. While James II shared his brother's passion for the theatre, the troubled years of his reign from 1685 to 1688 saw a general reduction of his engagement with theatrical activity (Howe 1992: 68). The shift from an aristocratic to a bourgeois public theatre may have made it more difficult for respectable, educated women to enter the stage as writers, for Elizabeth Polwhele and Aphra Behn could use their Royalist connections as routes of access. ${ }^{5}$ However, it may well be the case that this generation of women playwrights were discouraged from having their plays staged because the public

3. The first page of the manuscript provides evidence that Polwhele's The Faithfull Virgins was performed on the public London stage: "This tragedy apoynted to be acted by the dukes Company of Actors" (f.49). However, the date of The Faithfull Virgins cannot be determined specifically. Harbage's Annals (1964) state that the play was written and performed sometime between 1661 and 1663. According to Milhous and Hume (1977: 41), performance of the play probably took place around 1670 even if "the author was probably quite young".

4. As Marta Straznicky (1997: 703) argues, "one of the more striking ironies of English dramatic history" is that "the first era to have women become professional playwrights was also the first to foster a thoroughly privatized closet drama".

5. Polwhele, for instance, dedicated her comedy The Frolicks to prince Rupert, who may "spurn" her comedy "into nothing, if in anything it can offend you" (Milhous and Hume 1977: 57). Prince Rupert was an old friend and fellow cavalier exile of Thomas Killigrew, principal owner and manager of the King's Company, and Rupert's mistress was "the beautiful Margaret Hughes (or Hewes), who acted major roles for the King's Company from 1668 to Spring 1670" (Milhous and Hume 1977: 35). Therefore, Polwhele dedicated her work to a person who had good connections in the theatre world, and who could help her play on to the stage. Although Polwhele appears to have had a production of her third play in mind, there is no record of its performance. 
theatre was not respectable. Some actresses, such as Nell Gwynn, Frances Knight, Elizabeth Barry and Elizabeth Boutel, were notorious for their extramarital affairs (Howe 1992: 34), and had the reputation of being almost prostitutes: "Chestnutman'd Boutel whom all the Town F-ks" (Pearson 1988: 27).

Furthermore, after the performance actresses were literally sexually available to the male spectators in exchange for money. Men could easily go behind the scenes where the girls were undressing, the actresses not being offered protection against male assault. ${ }^{6}$ Male visitors would often pay to "chat with the actresses back-stage" (Bevis 1988: 34), thus offering money in return for intimacy with the actresses in the same way as they would pay prostitutes for sexual services. This practice was often referred to in the epilogues of Restoration plays. For example, in the epilogue of Dryden's Tyrannick Love (1670: K1v) the actress Nell Gwyn alludes to the fact that the gentlemen in the audience will soon come to see her backstage to satisfy their lust: "Gentlemen, make haste to me,/ I 'm sure ere long to have your company". In the epilogue of Nathaniel Lee's The Rival Queens (1677: L2v) even more explicit references are made to the backstage sexual intercourse with male members of the audience: "Our women who adorn each Play,/Bred at our Cost, become at length your prey". Because the theatre was generally associated with promiscuity, women dramatists were often accused of lasciviousness as well, Aphra Behn being an example in case.?

Despite an earlier decline in the number of women writing for the public stage, it is an undeniable fact that the mid 1690s were marked by an explosion of plays by women that were presented in the public theatres. As Allardyce Nicholl (1992: 75) states, from December 1695 to December 1696 "audiences saw no less than five new plays by female writers [...] Mrs Trotter's Agnes de Castro, Mrs Manley's The Lost Lover and The Royal Mischief, and Mrs Pix's Ibrabim and The Spanish Wives". In subsequent years, apart from Mary Pix, Delarivier Manley and Catherine Trotter, who wrote several other plays for the public stage, Susannah Centlivre and Jane Wiseman had tragedies and comedies performed in the public theatres. The enormous output of plays by women for the stage seems to have resulted from women's increasing influence as theatre managers by 1695. In March of that year a conflict over wages led the leading actors Thomas Betterton, Elizabeth Barry, Anne Bracegirdle, Mrs Bowman and Mrs Leigh to break away from the United Company, securing a license

6. See Howe (1992: 33): "regulations against backstage visitors were ineffectual".

7. In Prior's "A satyr on the Modern Translators" (1684), printed in Money Masters all Things: or, Sartirical Poems (1698: 119-20), Behn was depicted as a prostitute: "Then let her from the next inconstant lover,/ take a new copy for a second Rover/ describe the cunning of a jilting whore,/ From the ill arts herself has us'd before". 
to start their own company, Betterton's Company, in which the four actresses gained shares (Howe 1992: 29). The fact that Catherine Trotter's and Delarivier Manley's plays were performed by Betterton's company suggests a relationship between the influence of the women actresses in theatre management and the emergence of women's plays on the public stage. ${ }^{8}$ Despite this growing influence of women in the theatrical world during the late seventeenth and early eighteenth century, women dramatists working for the public stage ran the risk of being accused of lascivious behaviour. Writers of conduct books in late seventeenth-century England appear to have agreed on the quality that represented ideal femininity: modesty in speech. In The Ladies Calling (1673), Richard Allestree (1985: 43) commands that "a woman's tongue should indeed be like the imaginary music of spheres, sweet and charming, but not to be heard at a distance"; in other words, woman's voice should not be too emphatically present. Likewise, in The Ladies Dictionary (1694), Robert Codrington (1985: 40) argues: "I could content myself to wish in young gentlewomen those three perfections which Socrates desired in his disciples: discretion, silence and modesty". Whereas a woman's silence was generally seen as a mark of proper feminine submissiveness and chastity, woman's speech was commonly associated with lewd conduct. In view of the dominant idea that "It suits not with her honour for a young woman to be prolocutor" (Brathwaite 1631: Tt1r-v), a woman whose voice could be heard in public would often be accused of promiscuity.

Obviously, women dramatists' voices were audible in the public setting of the theatre in the form of the monologues and dialogues that they had written and that were frequently spoken by reputably loose women directly addressing a real audience: the actresses on stage. While the voice of the female dramatist was not directly audible on the Restoration public stage,? the epilogue to Aphra Behn's tragedy Abdelazer, or the Moor's Revenge (1677) indicates that the discourse expressed by the actress was often linked to the female playwright's voice: the actress impersonating Miss Ariell is presented as the defender of Behn the dramatist and the representative of the playwright's voice and views: "And for our Poetess will intercede".

The question arises how these women dramatists negotiated their own public voice as women dramatists in the light of the common equation of female selfexpression with promiscuity, and in view of the reputation of their mouthpieces,

8. In Three Augustan Women Playwrights Constance Clark (1986: 332) contends that these plays by the new generation of women writers were part of mainstream theatre.

9. As Ros Ballaster (1996: 268) claims: "the one figure who is emphatically not physically present on the stage in performance is the author herself, who appoints surrogates in the shape of actors to present prologues and epilogues on her behalf". 
the actresses, as sexually loose. Did these women dramatists endorse the dominant ideal of feminine silence in their plays as the means to cloak their own transgressive public voices; or, rather, did they seek to legitimise female utterance?

In this paper I will look at the ways in which women dramatists around 1700 negotiated their assumption of public theatrical discourse. As I hope to demonstrate through a reading of the tragedies The Royal Mischief (1696) by Delarivier Manley ${ }^{10}$, Catherine Trotter's The Fatal Friendship (1698) and Jane Wiseman's Antiochus the Great; or, The Final Relapse (1701) ${ }^{11}$ these women dramatists implicitly justified female self-expression by pointing out the social ideal of feminine silence as a tool through which men sexually manipulate and oppress the female sex, and by depicting female self-expression as an empowering quality for women through which they may gain control over their own lives. Moreover, these women dramatists legitimised female public discourse by associating women's speech with sexual and moral virtue in contrast with men's dishonourable words.

Furthermore, as I will show in the second part of my paper, these dramatists' legitimisation of women's public voice and their own public theatrical voices entailed a reconstruction of generic conventions. I will point out how these women playwrights' subversion of the common ideas about female speech is accompanied by a reconstruction of the current tragic codes of error, closure, transcendence and transgression. Through this analysis of women dramatists' contribution to transformations of gender and genre, I aim to point to the significant role played by these "female wits" in the processes of cultural change taking place during the early years of the long eighteenth century.

\section{2.}

A close look at tragedies by Delarivier Manley, Catherine Trotter and Jane Wiseman reveals that women dramatists writing for the public stage around 1700 deconstructed and challenged rather than supported the dominant ideology of feminine silence. Catherine Trotter's The Fatal Friendship (1698) exposes the common association between female self-expression and lasciviousness as the instrument through which men seek to oppress the female sex. ${ }^{12}$ In her tragedy the

10. Manley had an argument with the Drury Lane Company over the production of this play. This had prompted her to offer the play to Betterton at Lincoln's Inn Fields. As a result of her action, she was satirised by the Drury Lane actors in The Female Wits (1696). See Marcie Frank (2003: 121).

11. Wiseman's tragedy was performed at the Lincoln's Inn Fields Theatre in November 1701, but printed in 1702. See Emmett L. Avery (1960: 16).

12. As Anne Kelley (2002: 11) has suggested, critics have generally overlooked the "radical feminocentrism". 
heroine Felicia dares to speak up against her brother who wants to marry her off to the old Count Roquelaure, not being aware of his sister's secret marriage to the Count's son, Gramont. When Felicia dares to contradict her brother Bellgard as far as her consent to marriage is concerned, Bellgard initially responds to this defiance of his power by unjustly labelling his chaste and legally wedded sister a prostitute: "No, strumpet, he but served his lust with thee/Too wise to marry where he found no virtue" (III, ii). As the scene indicates, Bellgard seeks to regain his control over his sister and exact her obedience by interpreting her assertive speeches as signs of promiscuity. Furthermore, Trotter links her female characters' silence to their submission to the male sex. For instance, at first Felicia dares not confess her secret marriage to Gramont to her brother out of fear of the anger that she may provoke through her disobedient, unfeminine sexual agency: "Should I confess my marriage?/ Oh no, his fiery temper could not brook it" (I, i).

While Trotter clearly exposes the connection between woman's silence and a man's dominance over her, Wiseman implies that a woman who fails to speak up is rendered powerless. When her virtuous heroine Berenice is caught in a private interview with her former betrothed Ormades in order to reject his passion for her, she will not plead her innocence and faithfulness to her husband in order to defend her honour: "Let those whose Vertue stands in need of Art,/ Flie to such mean Designs to inhance their Merit; Mine needs no Floss; for Heaven and these can tell/ How inblamable I stand" (IV, i). However, Berenice's refutation of an assertive speech of self-defence leads to her suffering and further oppression by her husband Antiochus: Antiochus slays the virtuous Ormades and has Berenice confined.

Manley makes a similar point, creating the impression that a woman is disempowered by her silence. Bassima, who believes that "speaking is a crime" (III, i) fails to defend her own virtue when her husband Levan Dadian, Prince of Colchis, unjustly suspects her of adultery. Consequently, she is imprisoned and has her eyes put out. By contrast, the other female character, Homais, is shown to have more control over her fate as a result of her outspokenness. She manages to direct the events of the plot throughout the play. Her eloquence secures support from the armed forces, who defect to her side, and who submit to her orders, as is revealed by their words: "Your orders shall be straight obeyed" $(\mathrm{V}, \mathrm{i})$.

While Manley, Trotter and Wiseman challenge the social idealisation of feminine voicelessness by identifying woman's silence with oppression, they also deconstruct the common equation of female silence with virtue and obedience as well as undermine the association of woman's words with wantonness. In The Fatal Friendship a woman's silence is represented as a sign of disobedience and as concealing sexual agency. The widow Lamira, whose husband had laid down in his 
will that his wife would lose all her possessions if she were to remarry, will not publicise her marriage to Gramont in order to escape poverty. Her silence about her wedding is not only shown to be the result of men's oppression of women, but also covers up her acts of sexual independence and disobedience to her husband's will. Disconnecting woman's silence from the notions of obedience and sexual passivity, at the same time Trotter dissociates woman's self-assertion from sexual looseness. While Felicia openly expresses her defiance of her brother's command to marry the Count, voicing her "strong reluctance [...] For this unequal match" (I, i), she is at the same time a "dear example of fidelity" (IV, i) rather than dishonest, being bound to Gramont by a Priest "by all lawful bonds" of wedlock (III, ii).

Manley challenges the dominant gender discourses by pointing out that a woman who converses in private with any other man than her husband is not necessarily guilty of infidelity. Although Bassima meets her former lover Osman in private, she does not betray her husband. Her conversations with Osman are of an innocent nature, Bassima voicing her refusal to surrender to Osman's love and stressing her faithfulness to her legitimate husband, Levan Dadian: "For fenced about with chastity and glory,/ Which like a magic circle shall enfold me/ You must not hope to pass the sacred round" (III, i). The fact that Bassima, who fears "death of honour" (III, i) and who is "innocent as angels are,/ Free from the stain or wish of evil" (IV, i), is accused of adultery, issues from the distorted perceptions and hypocritical, false natures of those around her. Osman's wife Selima is blinded by an unjustified jealousy, which is stirred by Ismael, who seeks to obtain Selima's love by deliberately destroying Bassima and Osman's reputations. Levan Dadian's mistrust of his wife's virtue appears to be a projection of his own false, adulterous nature, for he has slept with Homais at an earlier stage of the play. The validity of the dominant gender ideology, which connects woman's transgressive speech with sexual incontinence, is questioned, for it is shown to be rooted in blindness, to be a projection of man's own lascivious nature and to be abused as a tool of manipulation.

A similar deconstruction of the dominant gender ideology can be found in Antiochus the Great. While Berenice has a private interview with her former beloved Ormades, who she had to abandon in order to obey her male relatives, she seeks to establish her virtue in this conversation, renouncing her former passion for Ormades and emphasising her constancy to her spouse. Antiochus' unjustified suspicion of his wife's faithfulness is caused by Artenor who deliberately spreads false rumours about Berenice's adultery so that his sister Leodice may regain Antiochus' affections: "I must prepare her for the great Design [...] Hint what thou hast heard/ With subtilty and caution, to Antiochus" (I, i). At the same time, the king 
is shown to be very inconstant himself, having abandoned his mistress Leodice, the mother of his son, for Berenice, and making amorous confessions to Leodice when he is married to Berenice. Thus it is suggested that Antiochus' mistrust of his wife is a figment of his own lascivious nature. While Berenice is represented as a chaste wife, she is also depicted as having a "transporting voice", "charms" in her "Words" and "bewitching Accents" (I, i). Wiseman undermines the conventional connection between woman's eloquence and wantonness, showing that the well-spoken Berenice is sexually virtuous.

Interestingly, while these female dramatists dissociate woman's self-expression from promiscuity, they identify men's words with bawdiness and unfaithfulness. In this respect they use a representation of male discourse that was common in seventeenth-century plays by both male and female dramatists, such as, among others, John Ford's 'Tis Pity She's a Whore (1633) and Margaret Cavendish's The Unnatural Tragedy (1662). ${ }^{13}$ In The Royal Mischief Ismael's words are often concerned with his lascivious sexual desires. He argues that he does not want to die before having enjoyed many beautiful women sexually: "I should never touch the West till I had/ bathed, nay, wantoned, in that sea of pleasure" (II, i). Furthermore, he voices fantasies about women who willingly cast off their modesty to make themselves sexually available:

They like the forward and the bold.

For virtue in such is like their form,

Only exterior beauty, worn to deceive

The credulous world and buy opinions

From the common rout.

But when they meet a lover to their wish

They gladly throw the borrowed veil aside

and naked in his arms disclose the cheat (II, i).

Moreover, although on the whole Osman is a virtuous character in the play, he nevertheless seeks to seduce the married Bassima into an adulterous affair:

13. In Ford's tragedy Giovanni uses his eloquence to corrupt his sister. He claims that his animal desire for his sister can be excused, as her "lips would tempt a saint; such hands as those,/ Would make an anchorite lascivious"(I, ii, 212-213). What occurs here is that Giovanni signifies Annabella's body as corrupting sexual purity, whereas, ironically, it is he who seeks to spoil Annabella's sexual innocence. In Cavendish's tragedy Frere openly speaks of his incestuous lust for his sister, and tries to persuade her into an incestuous relationship with him. In response to his sexually immoral plea she angrily remarks: "Brother, speak no more upon so bad a subject, for fear I wish you dumb: for the very breath that's sent forth with your words, will blister both my ears" (V, 31). 
"Who would not be ten thousand years a wretch/ To be one hour a God?" (III, i). In Wiseman's tragedy, Antiochus' speeches are implicated in adultery and deceit, for, when married to Berenice, he promises Leodice to renew his affair with her; a promise which he does not keep. Besides, when at last Antiochus changes his mind again in favour of Leodice he deliberately omits to tell her how his affections have been shifting all the time: "I'll not relate what Accidents have past,/ Till I have done what's worthy of my Change/ Lest she should think Revenge my only Motive" (V).

The contrast between men's deceitful, dishonourable speeches, on the one hand, and the female character's honest, virtuous words, on the other, in the tragedies is further enhanced by the fact that some of the male characters and their speeches are represented as irreligious. In Manley's The Royal Mischief Osman calls the way in which Ismael celebrates the wanton nature of the female sex "blasphemy" (II, i), considering the virtue of women like Bassima. In Wiseman's Antiochus Leodice claims that Antiochus' betrayal of their relationship implies that he is "false to every God, as well as me" (III, i). In Trotter's The Fatal Friendship Felicia argues that she does not want to be "impious" to her husband by abandoning him; this is in contrast with the fact that Gramont consented to a bigamous marriage through which he has "broke his faith" $(\mathrm{V}, \mathrm{i})$ with her. This association of the male dramatis personae and their speeches with impurity and blasphemy contributes to Manley's, Trotter's and Wiseman's positive, legitimising portrayal of female utterance.

\section{3.}

Challenging and revising the at that time common views on female selfexpression, Manley, Trotter and Wiseman prove to have revised the Restoration generic conventions of tragedy as well. Furthermore, their reconstruction of tragic error, transgression and transcendence involves a subversion of gender roles and gender ideas. This becomes clear when we compare and contrast the characterisation and tragic closure in The Royal Mischief, The Fatal Friendship and Antiochus, the Great to two earlier written tragedies by Nathaniel Lee: The Rival Queens (1677) and Lucius Junius Brutus (1681).

In English Restoration tragedy the tragic errors committed by female dramatis personae are usually a transgressive assertion of voice combined with sexual defilement outside the bonds of marriage. In The Rival Queens Roxana, the mistress of Alexander the Great, contrasts with his feminine wife Statira. Whereas Statira represents the legal wife who is marked for a modesty of sexuality and 
speech, Roxana is marked for her verbal aggressiveness: "hear me speak/ And mark me well, for fate is in my breath" (IV, i, 104-105). At the same time, Roxana has tempted Alexander into an adulterous affair: "because I practiced charms/ To gain the king" (IV, i, 188-189). Her adulterous sexuality and loose tongue appear to be her tragic errors through which she loses Alexander's love, who comes to despise her: "So will thy tongue undo all womankind" (III, i, 307-309). In Lucius Junus Brutus tragic error also appears to be a woman's destruction of her sexual honour. Shockingly, however, in the case of the female dramatis persona Lucrece, the error for which she must kill herself is a sexual defilement for which she is not responsible, since she was raped by Sextus. Lucrece considers herself bearing "the name of an Adultress" after her rape, and, to avoid having to "live beneath so loath'd an Infamy" she stabs herself to death.

The generation of female dramatists writing for the public stage by the end of the Restoration and the beginning of the eighteenth century clearly redefine tragic error in the sense that they represent the dominant gender roles and gender views as tragic mistakes. In The Royal Mischief Levan Dadian's tragic error is his suspicion of his wife's innocence despite her interview with Osman, as voiced in his moment of tragic recognition: "And Bassima that monster she was made./ O injured saint, dart from thy Heaven upon me" (V, i). Exposing the dominant gender discourses by connecting the hero's recognition of his tragic error to an awareness of the injustice of these dominant representations of female speech, Manley combines her reconstruction of the conventional representation of tragic error to a criticism on gender notions.

At a first glance Trotter seems to repeat the conventional Restoration tragic error as woman's transgression of the boundaries of feminine silence. Felicia claims that she has caused misery due to her unrestrained tongue: "Alas, "tis I have caused your infamy,/ My inconsiderate passion has exposed you./ What madness moved me to reveal the fatal secret!/ Was that a remedy!" (IV, i). However, at the same time this conventional depiction of female tragic error is undermined by Gramont's reply that Felicia has not sinned through her outspokenness, and by the fact that Felicia's honesty contrasts to Gramont's deceit which involved him in bigamy. In fact, the play indirectly suggests another daral flaw, namely adherence to gender conventions. Bellgard makes the mistake of misreading his sister's disobedience as a sign of her wantonness, so that the common equation between female self-assertion and promiscuity is exposed as an error.

Whereas tragic female characters who overstep the norms of femininity, such as Roxana, are usually portrayed in a negative way, Manley, Trotter and Wiseman display more sympathy for their female transgressors. While Trotter's Felicia goes 
against feminine submission by her sexual independence in choosing her own husband and by her disobedience to her brother, she is nevertheless a character who deserves the audience's sympathy. In comparison with Gramont's and Bellgard's secrecy and falsehoods, Felicia proves to be more honest. Her sin is also attenuated by the fact that she has become legally wedded to the lover that she has chosen, thus fitting in with the norms of propriety. Futhermore, in the final scene of the play emphasis is laid on Gramont's tragic error in the sense of his betrayal of both Felicia and Lamira: "he was by nature honest, just, and brave,/ In many trials showed a steady virtue,/ Yet by one sharp assault at last was vanquished" ( $\mathrm{V}, \mathrm{i})$. Transgression is thus mainly associated with the male protagonist Gramont.

Manley and Wiseman both depict women who are involved in an adulterous relationship. However, sympathy is created for the motivations underlying these women's entanglement in extramarital affairs. Leodice's endeavour to win back Antiochus' love, in spite of his marriage to Berenice, is shown to be connected to the fact that Antiochus had first exchanged vows with her, and with the fact that they had lived together like husband and wife with their son. Her poisoning of Antiochus issues from her desire to be forever united with Antiochus, albeit in death, and from her urge to avoid public shame as the rejected lover:

Inconstant Monarch, what could I do less?

Was I not scorn'd when Banish'd?

Now a Prisoner [...]

Yet think not 'twas Revenge alone that sway'd;

I too have drunk my Fate, and cannot live. (V, i)

Apart from this, Leodice's transgressive behaviour is balanced by her strong maternal affections and care. Leodice does not allow her servant to die with her so that her child will be looked after properly after she has died herself: "Oh, gold! Give me the Bowl; I had forgot my Child/ Thou must survive to guard his Innocence" (V, i). Moreover, before she dies Leodice expresses her regret at her sin of poisoning Antiochus, and is subsequently forgiven by him: "But why was not my fatal hand withheld? [...] Why dropt it not the black misguided Bowl?" (V). Thus, Kendall is right in stating that "Wiseman invites her audience to sympathize with the ragings of Leodice" (1988: 116), who is not represented as innately evil. Similarly, while Manley's Homais argues that "My life, my soul, my all is fixed upon enjoyment" (I, i), and while she commits adultery with Levan Dadian, Manley at the same time evokes understanding for Homais' unfaithfulness. Being the victim of an arranged marriage to an extremely possessive, impotent, elderly 
husband who confines her to his castle, Homais is "a woman, made/ Passionate by want of liberty" (I, i).

The three women dramatists also rewrote the conventions concerning the tragic closure. At the end of most Restoration tragedies the sexually and verbally transgressive woman is punished in several of the following ways: by being killed, by being silenced, by being transformed into a powerless being without autonomy over her own life or control over the plot, or by being confined to oblivion. Lee's Roxana conforms to the tragic stereotype of the wordy woman who is eventually deprived of her command over language. At the beginning of the tragedy Roxana possesses the ability to assert her voice despite Alexander's efforts to silence her. At the end of the play Roxana exclaims: "And that the memory of Roxana's wrongs/ may be forever printed in your mind" (IV, i, 101102). In other words, she wishes to remain a discursive presence in Alexander's thoughts. Despite Roxana's longing to signify herself as the remembered lover, Alexander denies her the status that she aims at. His remark "let her not be named" (III, i, 427) shows that he relegates her to the feminine realm of silence and forgetfulness. He imposes a figurative death upon her by denying her any existence in speech. Roxana also loses control in her role of plotter. Although she succeeds in her plot of mortally wounding Statira, Roxana's aim to win back Alexander fails utterly. It is Alexander who achieves direction over Roxana's fate in their final meeting. She must submissively "fly forever" from Alexander's sight when he commands: "Fly with thy pardon, lest I call it back" (V, i, 218-225). Disappearing from Alexander's life, Roxana silently disappears from the stage, thus being erased from the theatrical scene.

Manley and Wiseman revise the conventional tragic closure in many respects. Although Homais' ending accords with the fate conventionally reserved for the tragic transgressive female characters in that she dies, she transcends the silencing and erasure of identity that awaits her in death. Homais' death is preceded by her strong self-assertion. Homais suggests that it is her husband's fault that she has become adulterous, successfully shifting responsibility for her transgression to him: "Thou dotard, impotent in all but mischief,/ How could'st thou hope, at such an age, to keep/ A handsome wife?" (V,i). Whereas Roxana wishes to be the lover who is remembered, but fails in achieving this desired identity in her final appearance, Homais succeeds in establishing and controlling a self as a sympathetic adulteress. In contrast with Roxana whose disappearance from the stage suggests a complete obliteration of her identity, Homais argues that her death will not end her power, creating the impression that she will "feast at large" in an afterlife where at last she will be wedded to her lover Levan Dadian: "Be 
thou shade and let us mingle then/ Oh, I shall reign / A welcome ghost, the fiends will hug my royal mischief" (V, i). Thus, Homais transcends mortality as well as the control that her husband sought to exercise upon her.

Like Homais, Wiseman's Leodice transcends mortality. For one thing, Leodice controls her death; not only because she commits suicide, but also because she seems to be very consciously voicing her moment of death as if she were ready for it: "Death is at hand, 'tis wel, I feel him here:/ Welcome thou kind reliever of the Wretched,/ Met by the Brave, and only shun'd by Cowards" (V, i). By contrast, Antiochus feels that his time is cut short, so that he does not appear to be in command over death: "I do forgive thee, but can stay no longer" (V, i). Second, Leodice overcomes mortality in that she appears back on the stage after her death to speak the epilogue. While usually the epilogue is expressed by an actor or actress in their own person, in Wiseman's play it is clearly indicated in the stage directions that Leodice reappears to have the last word: "A Husband's Wrongs are always paid in kind: men's Stratagems but small Advantage get,/ And injur'd Women seldom die in Debt". This re-appearance of Leodice beyond the grave suggests a transcendence over death, which has not been able to silence her for good. Furthermore, voicing her idea that a man who abuses women deserves to be punished appears to be a justification of Leodice's revenge on him.

Berenice's fate at the tragic closure also marks a reconstruction of the conventional tragic plot. Usually, when the Restoration tragic heroine has lost her beloved she kills herself in order to follow him in death. For instance, in Lucius Junius Brutus Teraminta stabs herself to death when her husband Titus is dying: "Look here, my Love; thou shalt not be before me" (V, II). A remarkable difference between the plot in Lee's tragedy and Wiseman's tragedy is that Wiseman's heroine Berenice does not proceed to kill herself when her beloved Ormades has passed away. At the end of the play she is still alive and looking to the future, although she adopts a feminine part, forswearing the crown and returning it to her father: "But here I quit the gaudy empty Title: [...] And I am happy to resign the load[...] And lay my Crown at my Great father's feet" (V).

\section{CONCLUSION}

In Elizabeth Polwhele's tragedy The Faithful Virgins (ca. 1670) the unfaithful Isabella, forced to abandon her vows to Cleophon by her family, requests her former betrothed to "Vouchsafe an Eare" to her "discourse" (I), so that she may explain her situation. Cleophon responds to these assertive commands by stating: "What can you treat of but how false you Are?" (I), implying that when Isabella 
raises her voice it is only to acknowledge her wantonness, and silencing her imploring voice.

Issues of speech, silence and sexual virtue are also central to the tragedies written by Polwhele's successors: the women dramatists Manley, Trotter and Wiseman. As we have seen, in their plays, acted out on the late Restoration and early eighteenth-century London stage, these female dissociate woman's words from sexual looseness, they represented wit as an empowering quality through which women can survive, and thus present a woman's "Discourse" as a legitimate form of self-expression worth vouchsafing an "Eare" to. Furthermore, they unmask the dominant gender ideologies as projections of the immoral male mind as well as tools which men abuse to uphold their power over women. As such, The Royal Mischief, The Fatal Friendship and Antiochus the Great contain an emerging feminist consciousness.

Rewriting gender ideas about female utterance, these women dramatists also challenged the generic boundaries of tragedy which confined women to a restricted number of roles and representations. In their plays tragic error and recognition are not related to a woman's transgression of feminine norms; instead, the two generic elements are connected to ideas about womanhood which are exposed as false. In addition, these female "wits" have rewritten the conventions of the tragic closure which relegate women to silence and absence, while expressing more sympathy for those female characters who do not stick to feminine propriety. Manley's, Trotter's and Wiseman's active engagement with the processes of cultural transformation concerning gender and the tragic genre therefore make it essential for scholars of the period to "Vouchsafe an eare" to their dramatic "Discourse".

\section{REFERENCES}

Allestree, R. 1985 (1673). "The Ladies Calling”. The Whole Duty of a Woman: Female Writers in Seventeenth-Century England. Ed. A. Goreau. New York: Dial Press. 43-46.

Avery, E. L., ed. 1960. The London Stage, 1660-1800; A Calendar of Plays. Part 2: 1700-1729. Carbondale: Southern Illinois University Press.

Ballaster, R. 1996. "The First Female Dramatists". Women and Literature in Britain, 1500-1700. Ed. H. Wilcox. Cambridge: Cambridge University Press. 267-90.

Behn, A. 1677. Abdelazer, or The Moor's Revenge, a Tragedy as it is Acted at his Royal Highness the Duke's Theatre. London: printed for J. Mayne and R. Bentley.

Bevis, Richard W. 1988. English Drama: 1660-1789. New York: Longman. 
Brathwaite, Richard. 1641 (1631). The English gentlewoman. The English gentleman and The English gentlewoman Both in One Volume Couched. The 3rd edition. London: John Dawson.

Braun, B. 1995. Restoration Actresses during the Reign of Charles II. Trier: Wissenschadtlicher Verlag Trier.

Cavendish, M. 1662. The Unnatural Tragedy. Playes; Written by the Thrice Noble, Illustrious, and Excellent princess the Lady Marchioness of Newcastle. London: A. Warren for John Martyn, James Allestry, and Tho. Dicas.

Clark, C. 1986. Three Augustan Women Playwrights. American University Studies. New York: Peter Lang.

Codrington, R. 1985 (1694). "The Ladies Dictionary". The Whole Duty of a Woman: Female Writers in Seventeenth-Century England. Ed. A. Goreau. New York: Dial Press. 40-43.

Dryden, John. 1670. Tyrannick Love; or the Royal Martyr, a Tragedy, as it is Acted by his Majesties Servants, at the Theatre Royal. London: H. Herringman.

Ford, J. 1985 (1633). 'Tis Pity She's a Whore. 1985. Ed. K. Sturgess. London: Penguin.

Frank, M. 2003. Gender, Theatre, and the Origins of Criticism. Cambridge: Cambridge University Press.

Howe, E. 1992. The First English Actresses: Women and Drama, 1660-1700. Cambridge: Cambridge University Press.

Kelley, A. 2002. Catharine Trotter: An Early Modern Writer in the Vanguard of Feminism. Aldershot: Ashgate.

Lee, N. 1970 (1677). The Rival Queens. Ed. P. F.Vernon. London: Edward Arnold.

—, 1681. Lucius Junius Brutus. London: R. and J. Tonson.

Manley, M. D. 1696. The Royal Mischief, a Tragedy. London.

Milhous, J., and R. Hume, eds. 1977 (1671). Elizabeth Polwhele, The Frolicks, or The Lawyer Cheated. Ithaca: Cornell University Press.

Nicholl, A. 1992. History of English Drama 1660-1700. Vol 1. Cambridge: Cambridge University Press.

Pearson, J. 1988. The Prostituted Muse: Images of Women and Women Dramatists. Brighton: Harvester.

Polwhele, E. C. 1670. The Faithful Virgins. MS. Rawls Poet. 195. Ff. 49-78. The Bodleian Library.

Prior, M. 1698 (1684). "Satyr on the Modern Translators". Pecunice obediunt omnia. Money masters all things: or, satyrical poems, shewing the power and influence of money over all men. London. 117-22. 
Straznicky, M. 1997. "Restoration Women Playwrights and the Limits of Professionalism". English Literary History 64: 703-26.

Trotter, C. 1698. The Fatal Friendship, a Tragedy. London.

Wharton, A. 1688. Love's Martyr; or, Witt above Crowns. British Library: Add. MS 28, 693.

Wiseman, J. 1701. Antiochus the Great; or, The Final Relapse. London. 